\title{
Cellular retinol binding protein 1 transfection reduces proliferation and AKT-related gene expression in H460 non-small lung cancer cells
}

\author{
Amedeo Ferlosio $^{1}$ - Elena Doldo ${ }^{1} \cdot$ Sara Agostinelli ${ }^{1} \cdot$ Gaetana Costanza $^{1,2} \cdot$ Federica Centofanti $^{1} \cdot$ Angelo Sidoni $^{3}$. \\ Augusto Orlandi ${ }^{1,4,5}$
}

Received: 10 March 2020 / Revised: 13 August 2020 / Accepted: 28 August 2020 / Published online: 9 September 2020

(c) The Author(s) 2020

\begin{abstract}
In recent years, new treatments with novel action mechanisms have been explored for advanced non-small cell lung cancer (NSCLC). Retinoids promote cancer cell differentiation and death and their trafficking and action is mediated from specific cytoplasmic and nuclear receptors, respectively. The purpose of this study was to investigate the effect of Cellular retinol binding protein-1 (CRBP-1) transfection in H460 human NSCLC cell line, normally not expressing CRBP-1. H460 cells were transfected by using a vector pTargeT Mammalian expression system carrying the whole sequence of CRBP-1 gene. For proliferation and apoptosis studies, cells were treated with different concentrations of all-trans Retinoic Acid (atRA) and retinol. AKT-related gene expression was analyzed by using western blot and Signosis array and results analysed by one-way analysis of variance (ANOVA) or by t-student test. CRBP- $1^{+}$showed reduced proliferation and viability in basal condition and after atRA treatment when compared to empty-transfected $\mathrm{H} 460$ cells. Reduced proliferation in CRBP- $1^{+}$ $\mathrm{H} 460$ cells associated to the down-regulation of pAKT/pERK/pEGFR-related genes. In particular, gene array documented the down-regulation of AKT and Stat-3-related genes, including M-Tor, Akt1, Akt2, Akt3, Foxo1, p27, Jun. Restoration of CRBP-1 expression in $\mathrm{H} 460$ cells reduced proliferation and viability in both basal condition and after atRA treatment, likely by down-regulating AKT-related gene level. Further studies are needed to better clarify how those CRBP-1-related intracellular pathways contribute to counteract NSCLC progression in order to suggest a potential tool to improve efficacy of retinoid anti lung cancer adjuvant therapy.
\end{abstract}

Keywords Non-small cell lung cancer $\cdot$ CRBP- $1 \cdot$ AKT pathway $\cdot$ Retinoids

Amedeo Ferlosio and Elena Doldo have equally contributed as first authors.

Augusto Orlandi

orlandi@uniroma2.it

1 Anatomic Pathology, Department of Biomedicine and Prevention, Tor Vergata University of Rome, Rome, Italy

2 Dermapathology laboratory, San Gallicano Institute, Rome, Italy

3 Department of Experimental Medicine, Section of Anatomic Pathology and Histology, Medical School, University of Perugia, Perugia, Italy

4 Department of Anatomic Pathology, Tor Vergata Policlinic of Rome, Rome, Italy

5 Institute of Anatomic Pathology, Dept. of Biomedicine and Prevention, Tor Vergata University of Rome, Via Montpellier, 00133 Rome, Italy

\section{Introduction}

Lung cancer is the first cause of neoplastic death worldwide in both men and women population [1]. Non-small cell lung carcinoma (NSCLC) accounts for $80 \%$ of all cases. Nevertheless the recent progress in NSCLC therapy with the advent of personalized medicine, only $18 \%$ all patients are still alive after 5 years from diagnosis [2]. In lung cancer, Vitamin A (retinol) deficiency has been associated with bronchial metaplasia and increased cancer development [3-5]. Retinoids (retinol derivatives) showed to promote differentiation and cell death of cancer cells in a number of experimental systems, including lung [5-7]. In recent years, new treatments with novel action mechanisms have been explored for advanced lung cancer, including retinoids administration $[3,7,8]$. Biological activity of retinoids, in particular all-trans retinoic acid (atRA) is normally mediated by specific cytoplasmic and nuclear receptors [8-10]. 
Cellular retinol binding protein-1 (CRBP-1) is a $15 \mathrm{kDa}$ cytosolic binding protein crucial for uptake and subsequent esterification of retinol, by regulating its bioavailability $[8$, 11]. CRBP-1 is indispensable for embryonic development and growth of vertebrates. In the lung parenchyma, CRBP-1 expressing cells are observed during development and prenatal alveolus formation [12]. Defects in CRBP-1 gene expression linked to oncogenic process in breast, prostatic, renal, lung and endometrial cancer [13-15]. Retinoids exert their pleiotropic and transcriptional effects binding nuclear receptors, namely the retinoic acid receptors $\mathrm{RAR} \alpha, \beta$, and $\gamma$, and retinoid X receptors $\operatorname{RXR} \alpha, \beta$, and $\gamma[5,8,10,16]$. RARs may form homodimers $[17,18]$ or heterodimers with other receptors as thyroid hormone receptors, Vitamin D3 receptors, peroxisome proliferator active receptors (PPARs) and several orphan receptors, contributing to starting alternative signalling pathways [19]. For example, RAR $\beta$ and $\mathrm{RXR} \alpha$, in normal respiratory epithelium, binding PPAR $\gamma$ with other cofactors, ensures cyclin D1 mediated cell cycle inhibition hence favouring apoptosis or differentiation [5, 18]. Down regulation of RAR $\beta$ combined with AP- 1 upregulation triggers tumour progression and proliferation of NSCLC cells [20]. Concurrently, the inability of RXR $\alpha$ to form heterodimers with PPAR $\gamma$ enables an AP-1/CRBdependent up regulation of Cox 2 , resulting in inhibition of apoptosis [16, 21]. The loss of RAR $\beta$ mRNA expression has been observed in many lung cancer cells line and its expression is contingent on intracellular concentration of retinoids, mediated by CRBP-1 and 2 [20]. Moreover, retinoids can activate several pathway, including AKT/ERK signalling in lung cancer cells through a transcriptional independentmechanism [3, 22]. Retinol can induce cytokine-dependent activation of Jak2 and subsequently STATs transcription factor, while the exchange from RBP to intracellular CRBP-1 is mediated by Stra6 receptor [23].

We recently documented that high expression of CRBP-1 in lung adenocarcinoma in vivo was associated to a lower overall survival [24]. Napoli et al. proposed that CRBP-1 expression in NSCLC should be considered as marker of RAR $\beta$ down regulation [8]. In fact, authors suggested that CRBP-1 cytoplasmic accumulation represent a block of nuclear availability of retinoids.

In this preliminary study, we investigated the effect of atRA in native and CRBP-1-transfected $\mathrm{H} 460$ lung cancer cells with particular reference to the modulation of RAR/ RXRs and pAKT/pERK/pEGFR gene signaling. We highlighted that the restoration of CRBP-1 influenced the proliferation and AKT signalling pathway in $\mathrm{H} 460$ cell line also in the presence of $a t \mathrm{RA}$ treatment.

\section{Methods}

\section{Cell transfection}

Human non-small cell lung cancer H460 cell line (kindly provided by Dr. Carlo Leonetti, Regina Elena National Cancer Institute, Rome, Italy) maintained in RPMI 1640 (Lonza Bio Pharma AG, Switzerland) and transfected by using a vector pTargeT. Mammalian expression system carrying the whole sequence of CRBP-1 gene (NM_002899) and the gene for the resistance to G418 (Promega, Italy), or the G418-resistance gene alone, as reported [25]. After 20 days, stable transfected clones were collected in G418-containing medium and tested by PCR and western blot. The correct plasmid sequence confirmed by Sanger sequencing. Experimental procedures were repeated by using different transfected clones, which gave similar results (data not shown).

\section{Cell growth, viability and clonogenic assay}

For proliferation studies, native and transfected H460 cells were treated with different concentrations of atRA (R 2625; Sigma-Aldrich, St. Louis, USA) and retinol (R7632; Sigma-Aldrich, St. Louis, USA) in 0.1\% FBS (Fetal Bovine Serum, Sigma-Aldrich) up to 3 days. For cell viability, 3-(4,5-dimethylthiazol-2-yl)-2,5diphenyltetrazolimbromide assay (MTT, Sigma-Aldrich) was performed [26]. For the clonogenic assay, after seeding and overnight serum-starving, cells were maintained with $10 \%$ or $0.1 \%$ of FBS and treated with $5 \mu \mathrm{M}$ atRA. Colonies arising from survival cells were fixed and stained with $1 \%$ methylene blue (Sigma-Aldrich) in $0.1 \%$ methanol and their percentages as plating efficiency (PE) calculated [24].

\section{Gene expression analysis}

Gene expression analysis was performed using Signosis array (Signosis, Inc., Santa Clara, CA, USA). Briefly, total RNA was extracted [27, 28], reverse-transcribed into cDNA in the presence of biotin-dUTP and a profile of 24 genes for human AKT and Stat-3 pathway cDNA plate array (Catalog number AP-0161 and AP-0151 respectively; Signosis). Luminescence relative light units (RLUs) was evaluated on a microplate luminometer, according to the manufacturer' instruction. Real-time PCR for RXR, RARs and cytokeratins was also performed in triplicate using $\beta 2$-microglobulin, $\beta$-actin and glyceraldehyde3 -phosphate dehydrogenase (GAPDH) as housekeeping genes, as previously reported [24]. 


\section{Western blot analysis}

After isolation, content determination and electrophoresis, proteins were elettroblotted [29] and incubated with a polyclonal rabbit anti-CRBP-1, anti-RXR $\alpha$, anti-RAR $\alpha$ (1:500, Santa Cruz Biotechnology, USA), anti-RAR $\beta$, anti-RAR $\gamma$, anti-cytokeratin-5/6, anti-cytokeratin-10 (1:500, Abcam, Cambridge, UK), anti-phosphorylated-AKT (pAKT Ser ${ }^{473}$ ), anti-AKT, anti-phosphorylated ERK1/2, anti-phosphorylated EGFR (Thr669) and mouse anti-total tubulin antibody (Sigma-Aldrich), followed from horseradish peroxidase conjugate goat anti-rabbit or anti-mouse IgGs (Pierce, Rockford, USA). Specific complexes were revealed and quantified as reported [29] in three independent experiments. AKT and EGFR activity expressed as phospho/total protein ratio [30].

\section{Patients and methods}

Paraffin blocks of tumors of a small cohort of patients with histologic diagnosis of NSCLC (Santa Maria della Misericordia Hospital of Perugia, Italy) were included. Tumor classification was in accordance with WHO criteria and the most diffuse immunohistochemical panel. For CRBP-1 positive and negative expression, tissue sections were incubated for $1 \mathrm{~h}$ with rabbit polyclonal anti-CRBP-1 (1:200; clone FL-135, Santa Cruz Biotechnology, Heidelberg, Germany). Diaminobenzidine was used as final chromogen. CRBP-1 expression was estimated at $\times 400$ magnification by two of the Authors by using the following semi-quantitative grading system: absent and strongly positive expression. This retrospective study was approved by Ethics Committee, waiving patient consent.

\section{Statistical analysis}

Results were analysed as the arithmetical mean \pm SD Data were analyzed by one-way analysis of variance (ANOVA) followed from a Bonferroni post hoc test or using the Student $t$-test. The differences were considered statistically significant for $p$ values $<0.05$. All the statistical analyses performed with SSPS V.20 (Stat Corp, College Station, TX, USA).

\section{Results}

\section{Restoration of CRBP-1 expression reduces survival and clonogenicity of H460 cells}

As reported in Fig. 1a, b, empty-transfected H460 cells did not express CRBP-1, similarly to native cells. To investigate the effect of CRBP-1 transfection on $\mathrm{H} 460$ cell survival, cell counting and MTT assay were performed. Our results showed that $10 \%$ FBS-cultured CRBP- $1^{+}$grew less than empty-transfected $\mathrm{H} 460$ cells starting from 2nd day $\left(p<0.05\right.$; Fig. 1c). CRBP- $1^{+}$viability was also reduced more markedly in the presence of different atRA concentrations $\left(1-20 \mu \mathrm{M} ; \mathrm{IC}_{50}=5 \mu \mathrm{M}\right.$; Fig. 1d) when compared to empty-transfected H460 cells. Finally, CRBP- $1^{+} \mathrm{H} 460$ maintained with $10 \%$ and $0.1 \%$ of FBS and after $48 \mathrm{~h}$ of $5 \mu \mathrm{M}$ atRA treatment showed a poor ability to form colonies compared to empty-transfected H460 cells (Fig. 1e, f).

\section{CRBP-1 transfection influences proliferative and transcriptional gene levels of $\mathrm{H} 460$ cells}

In order to investigate the CRBP-1-regulated intracellular signalling, gene expression and western blotting analysis were performed. A series of genes involved in AKT and Stat-3-related proliferation pathways resulted modulated in CRBP $-1^{+} \mathrm{H} 460$ compared to empty-transfected $\mathrm{H} 460$ cells. The down-regulated genes were: 14-3-3-sigma, 4E-BP, Enos, m-Tor, Akt1, Akt2, Akt3, Foxo1, Foxo3, p21, p27, p70, PDK1, Bad, PI3K, PTEN, Casp9, A2M and Jun; while Mdm2, Gsk-3a, IGF-1R, C-myc, CRP, Cyclin-E, MCL1, DNMT1, Bcl-2, GP130, Bcl-xl, GSK-3B, C-fos resulted upregulated (Fig. 2a, b). Overall, CRBP-1 expression seemed to reduce the expression of proliferative proteins and to increase the expression of differentiation markers. Moreover, we documented the upregulation of cytokeratin- 1 and 10 $(p<0.02$ and $p<0.01$, respectively) and the down-regulation of cytokeratin-5 $(p<0.01)$ expression in CRBP- $1^{+}$compared to empty-transfected $\mathrm{H} 460$ cells; protein expression for gave similar results (Fig. 3a, b).

In basal condition (10\% of FBS), RAR $\alpha$ protein expression resulted modulated in $\mathrm{CRBP}-1^{+} \mathrm{H} 460$ compared to empty-transfected $\mathrm{H} 460$ cells, whereas CRBP-1 did not significantly influence RAR $\beta$, RARy, and RXR $\alpha$ expression (Fig. 3c). As reported in Fig. 3d, we observed the reduction of pAKT expression $(p<0.05)$, but no significant difference in pERK and pEGFR expression in serum-cultured CRBP$1^{+}$compared to empty-tranfected H460 cells. Moreover, we showed the downregulation of pAKT $(\mathrm{p}<0.05)$, pERK $(\mathrm{p}<0.05)$ and pEGFR $(\mathrm{p}<0.5)$ expression after $48 \mathrm{~h}$ of $5 \mu \mathrm{M}$ at RA treatment. Instead, ROL treatment did not influence protein modulation (Fig. 3e-g).

\section{CRBP-1 expression influences AKT signaling pathway in vivo}

To further investigate if CRBP-1 positive expression could modulate AKT pathway in vivo, a preliminary gene array was performed. One patient with $\mathrm{CRBP}-1^{+}$tumor and one patient with CRBP-1 ${ }^{-}$tumor expression were analysed. As reported in Fig. 4, genes implicated in AKT pathway resulted down-regulated, whereas only PTEN was up-regulated. 
A

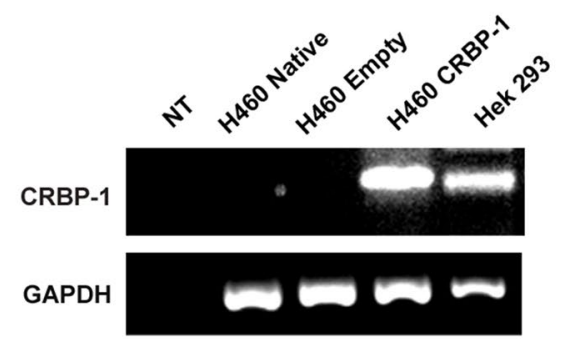

C

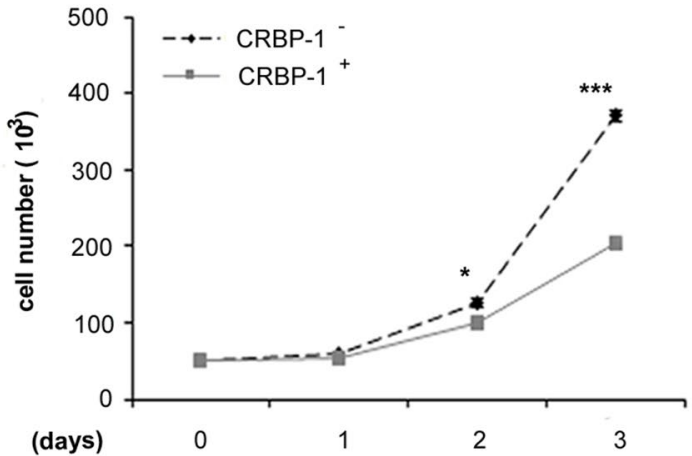

E

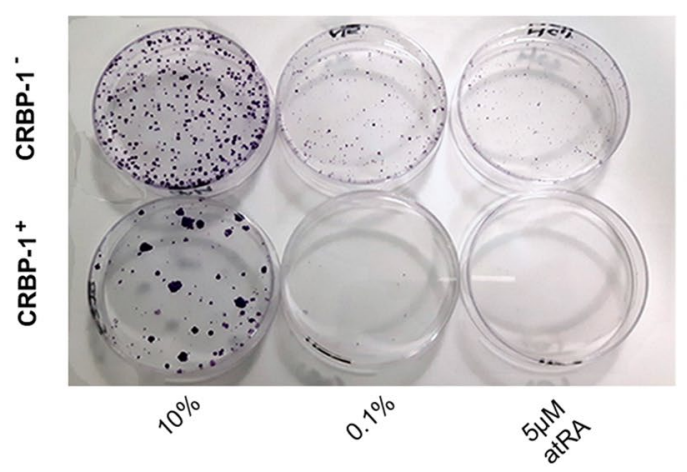

Fig. 1 CRBP-1 transfection reduces viability and retinoid-related survival of $\mathrm{H} 460$ cells. a RT-PCR and b representative blots of protein expression in CRBP-1-transfected in H460 cell line. Hek-293 cells as positive control. c CRBP- $1^{+} \mathrm{H} 460$ cells growth increased compared to empty-transfected cells. d MTT assay shows reduced viability of $\mathrm{CRBP}-1^{+}$compared to empty-transfected H460 cells after 2

\section{Discussion}

The $\mathrm{H} 460$ cell line represents a suitable experimental model of highly proliferative, drug-resistant, metastatic NSCLC cell line [7]. Recently, it has been demonstrated the presence of cancer stem cells in $\mathrm{H} 460$ cell line [31] thus explaining at least in part its aggressiveness. It is well documented that chemio and radiotherapy resistance is mainly due to so-called cancer stem cells selection, epigenetic mechanisms silencing physiological pathway (for example hypo
B
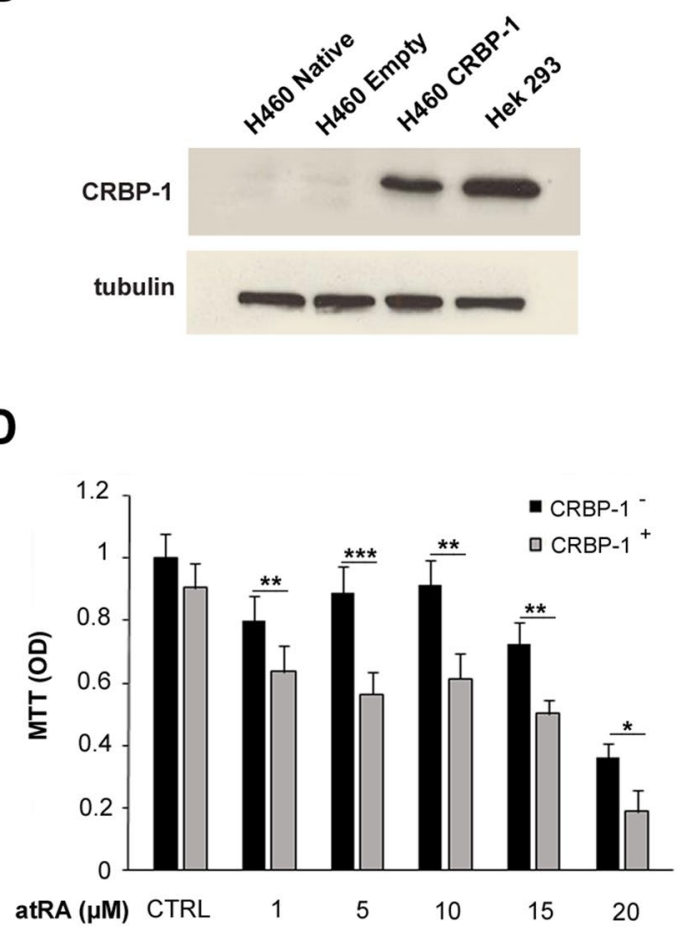

$\mathbf{F}$

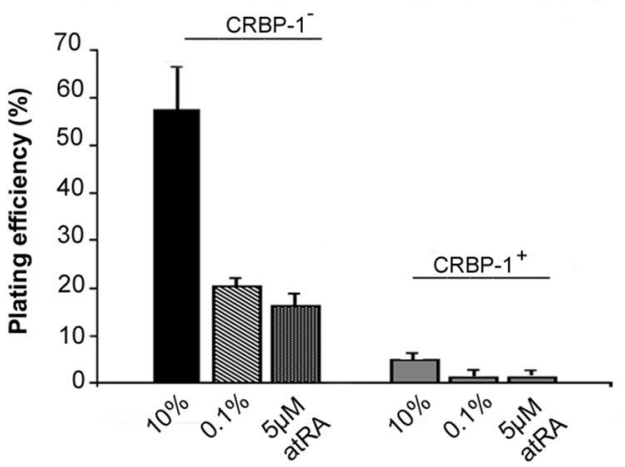

days of atRA treatment in the presence of $0.1 \%$ FBS. e, f CRBP- $1^{+}$ maintained with $10 \%$ and $0.1 \%$ of FBS and after $48 \mathrm{~h}$ of $5 \mu \mathrm{M}$ atRA treatment showed a poor ability to form colonies compared to emptytransfected H460 cells. Values expressed as means \pm SD of three different experiments: ${ }^{*} p<0.05, * * p<0.005, * * * p<0.001$

or hypermethilation of genes) and finally the acquisition of mutations [32]. In fact, also with the promising tyrosine kinase inhibitors or the immunotherapy patients develop inevitably progression [28, 33, 34]. AtRA is well known to have a dramatic effect on M3 subtype of acute myeloid leukemia [34]. However, in most other cancers this effect was not observed because of epigenetic silencing of retinoid pathway [35]. Low doses of $a t \mathrm{RA}\left(20 \mathrm{mg} / \mathrm{m}^{2} /\right.$ day $)$ in combination with chemotherapy showed remarkable activity as demonstrated in a randomized phase II trial of patients 

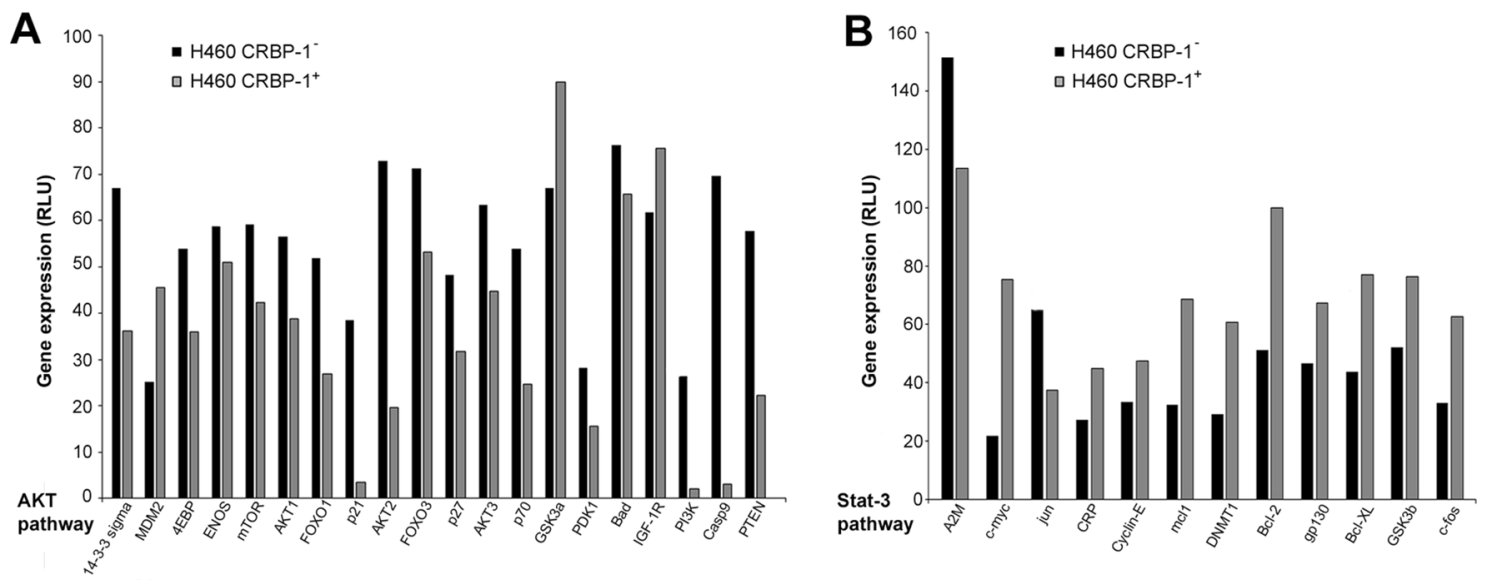

Fig. 2 CRBP-1 transfection influences transcriptional pathways and differentiation of H460 cells. a, b Bar graph of gene array showed gene modulation of Akt and Stat-3 pathways in CRBP- $1^{+}$compared to empty-transfected $\mathrm{H} 460$ cells

A

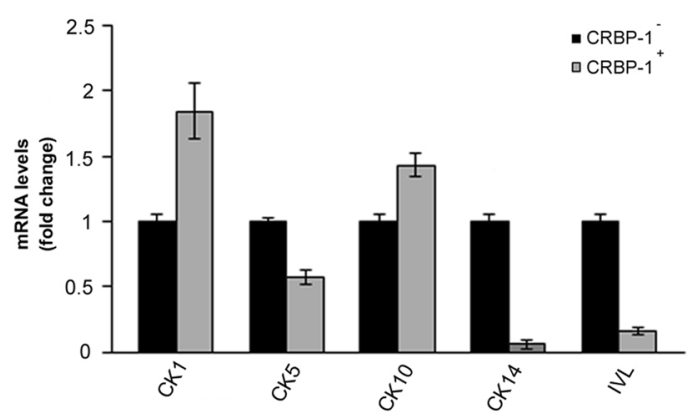

C
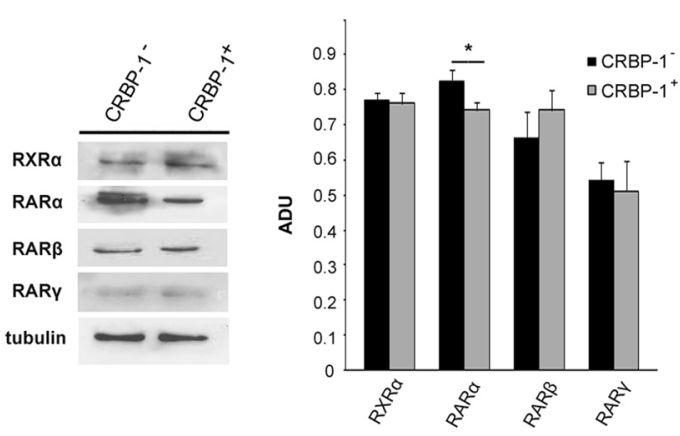

E

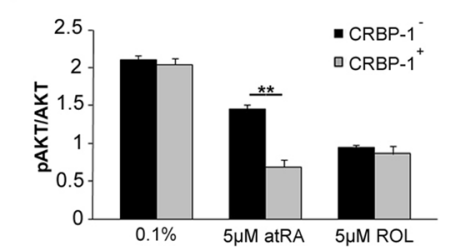

B

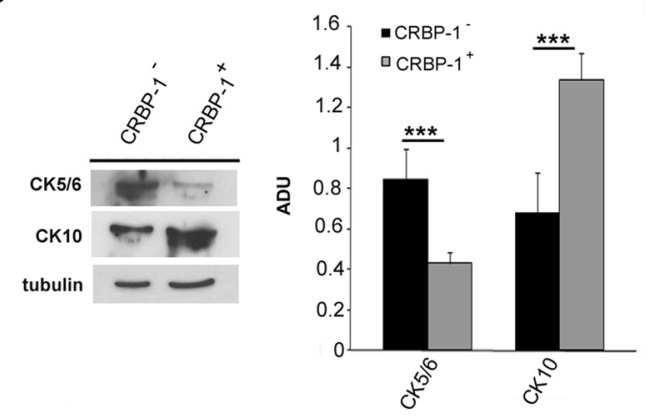

D
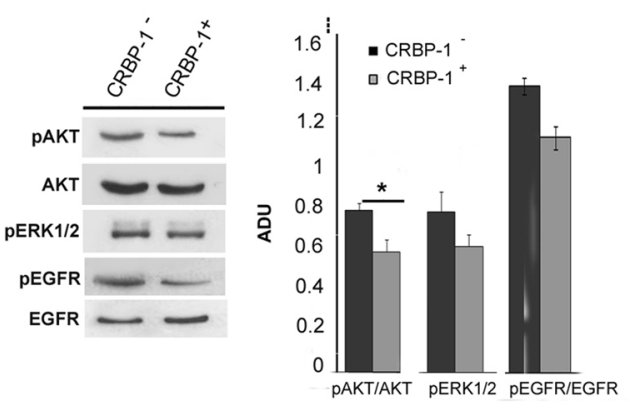

G

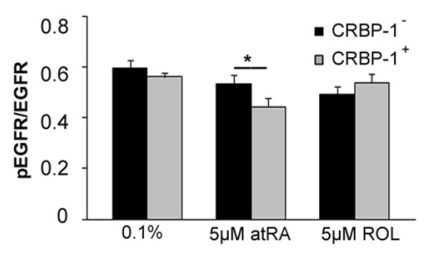

Fig. 3 CRBP-1 transfection modulates cytokeratins and Aktrelated genes and protein expression in $\mathrm{H} 460$ cells. a Cytokeratins mRNA levels by real-time PCR; representative blot and bar graph of cytokeratins (b), RARs/RXR (c), pAKT/AKT, pERK1/2 and $\mathrm{pEGFR/EGFR} \mathrm{(d)} \mathrm{protein} \mathrm{expression} \mathrm{in} \mathrm{CRBP-} 1^{+}$compared to empty-tranfected $\mathrm{H} 460$ cells maintained with $10 \%$ FBS; $\mathbf{e}-\mathbf{g}$ Bar graphs of pAKT/AKT, pEGFR/EGFR and pERK1/2 protein expression in CRBP- $1^{+}$compared to empty-tranfected $\mathrm{H} 460$ cells after $48 \mathrm{~h}$ of treatment with $5 \mu \mathrm{M}$ atRA and ROL. $* p<0.05$, ** $p<0.005$ and *** $p<0.001$. $R L U$ relative light unit, $A D U$ arbitrary densitometric units 


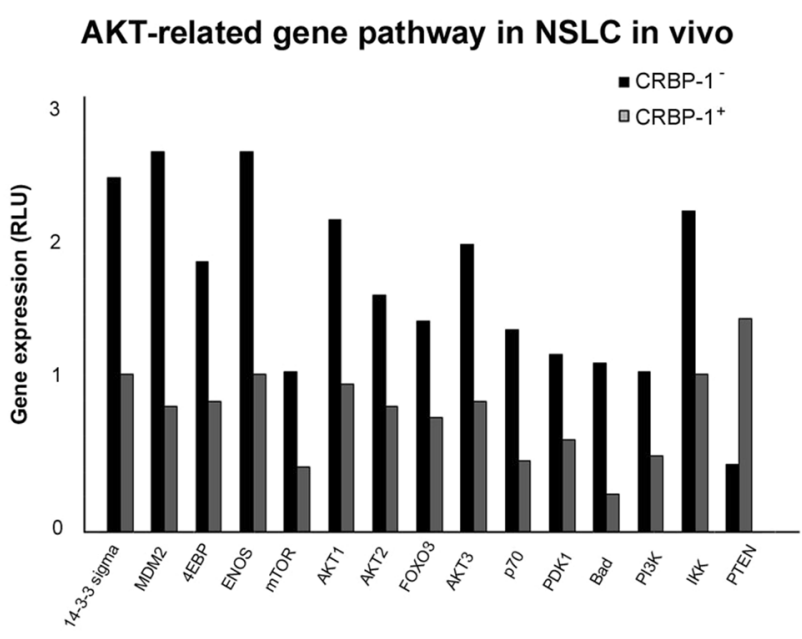

Fig. 4 CRBP-1expression associates to modulation of AKT-related genes in NSCLC tissue. Bar graph of gene array showed the modulation of Akt-related gene in CRBP-1 positive compared to CRBP-1 negative NSCLC tissue samples

with advanced NSCLC [6]. Our results showed a reduced viability and the down-regulation of several genes and proteins involved in proliferative and transcriptional pathways in $\mathrm{CRBP}-1^{+}$compared to empty-transfected $\mathrm{H} 460$ cells in both basal condition and after $a t \mathrm{RA}$ treatment. AtRA is often used in clinical trials to suppress the growth and progression of different cancer types $[18,36]$. However, its effectiveness is limited in some cancer, including lung cancer $[6,37,38]$. AtRA is an active metabolite of Vitamin A that regulates diverse cellular functions such differentiation, proliferation and apoptosis by binding with RAR/RXR receptors [8]. RAR $\beta$ is a tumor suppressor gene whose expression is significantly decreased in human cancers and increased with atRA treatment [39]. The loss of RAR $\beta$ mRNA expression has been observed in many lung cancer cells lines and its expression is influenced from intracellular concentration of retinoids, mediated by CRBP-1 [20]. Besides trafficking, CRBP-1 loss is responsible for intracellular retinoid deficiency, since CRBP-1 is required for retinol bioconversion [40-42]. Epidemiological studies suggested that the addition of atRA or synthetic retinoids to human cancer cell lines or human tumor xenografts in nude mice results in a cell growth arrest, apoptosis or differentiation [43]. Expression of CRBP-1 may help to switch between a proliferative and differentiative phenotype in response to oncogenetic stimuli [44]. It has been reported that in human mammary tumor cells the reintroduction of CRBP-1 reduces tumorigenicity in athymic mice [45]. Moreover, the inhibition of PI3K/Akt pathway was involved in the antitumor effect of CRBP-1 mediated from p 85 regulatory and p1 10 catalytic subunit heterodimerization [46]. It is possible to hypothesize that re-expression of PI3K/Akt signaling mediates CRBP-1 loss-induced cancer progression and RAR $\beta$ down-regulation in a transcription-independent mechanism of action of $a t$ RA.

Several in vitro studies showed that atRA induces a transcription-independent activation of the PI3K/Akt pathway $[18,24]$. For that reason, we transfected H460 lung cancer cell line with CRBP-1 and compared the effect of at RA in Akt signalling and RAR expression. We observed that restoration of CRBP-1 expression in $\mathrm{H} 460$ cells reduces survival and clonogenicity compared to emptytransfected cells. Moreover, CRBP- $1^{+} \mathrm{H} 460$ cells showed a poor ability to form colonies compared to $\mathrm{CRBP}-1^{-}$cells, both in basal condition and after $48 \mathrm{~h}$ of $a t \mathrm{RA}$ treatment.

A series of genes involved in Akt and Stat-3 related proliferation pathways were down-regulated in CRBP$1^{+} \mathrm{H} 460$ cells as Akt1, Akt2, Akt3, Foxo3, p21, p27, p70, Casp9, Gsk-3a, IGF-1R, PI3K, C-myc, Cycline-E, whereas, Bcl-2, GP130, Bcl-xl, GSK-3B, C-fos genes were up-regulated. Those findings confirmed the hypothesis that CRBP-1 expression in $\mathrm{H} 460$ cells reduces the expression of proliferative and increases that of differentiation markers. As concerning cytokeratin expression, we observed the upregulation of cytokeratin-1 and 10 and the downregulation in cytokeratin-5 expression in $\mathrm{CRBP}-1^{+}$compared to empty-transfected $\mathrm{H} 460$ cells. In basal condition, CRBP- $1^{+} \mathrm{H} 460$ cells showed a significant reduction of pAKT protein expression, but no significant difference in pERK and pEGFR expression. A greater and significant downregulation of pAKT, pERK and pEGFR in CRBP$1^{+}$compared to empty-transfected $\mathrm{H} 460$ cells was documented after $48 \mathrm{~h}$ of $5 \mu \mathrm{M}$ at RA treatment, but not after retinol treatment. As possible explanation, it has been reported that genes related to retinoid biosynthesis, transport, degradation and signaling are deregulated in most NSCLC [47], possibly explaining at least in part those contradictory results. In particular, retinol is transformed in retinal through many enzymes, all of which may be inactivated or non-functioning [47]. Finally, we showed that RAR $\alpha$ expression was decreased and RAR $\beta$ increased in $\mathrm{CRBP}-1^{+}$where compared to empty-transfected $\mathrm{H} 460$ cells. Therefore, CRBP-1 restoration influenced proliferation and AKT signaling pathway in $\mathrm{H} 460$ cell line also in the presence of atRA treatment. Both atRA and retinol were dissolved in DMSO, which acts as a histone deacetylase inhibitor. The DMSO action could be a limitation in our study. Nevertheless, being used for the dissolution of both drugs, the differences reported cannot be due to the presence of DMSO. Finally, further studies are needed to define the at RA role in $\mathrm{CRBP}-1^{+} \mathrm{H} 460$ cell line and to clarify if those CRBP-1-related pathways involved in NSCLC carcinogenesis may be modulated, with a potential beneficial opportunity for a more personalized chemotherapeutic regimens employing adjuvant retinoid therapy. 
Acknowledgements We thank Dr. Carlo Leonetti Regina Elena National Cancer Institute, Italy, for H460 cells providing.

Author contributions AF, ED, AO conceived the research. AS provided human tissue samples. ED and SA performed experiments. FC helped to perform experiments. GC analyzed the data. AF and ED wrote the manuscript. GC helps to write the manuscript. AO revised the manuscript and supervised the study. All authors read the paper and approved the final manuscript.

Funding Open access funding provided by Università degli Studi di Roma Tor Vergata. This work funded by Prof. Orlandi personal research funds.

Data availability The datasets used and/or analyzed during the current study are available from the corresponding author on reasonable request.

\section{Compliance with ethical standards}

Conflict of Interest The authors declare no conflicts of interest.

Ethics approval Local Ethics Committee no. 4796/15/AV, Comitato Etico Aziende Sanitarie (CEAS) Umbria.

Open Access This article is licensed under a Creative Commons Attribution 4.0 International License, which permits use, sharing, adaptation, distribution and reproduction in any medium or format, as long as you give appropriate credit to the original author(s) and the source, provide a link to the Creative Commons licence, and indicate if changes were made. The images or other third party material in this article are included in the article's Creative Commons licence, unless indicated otherwise in a credit line to the material. If material is not included in the article's Creative Commons licence and your intended use is not permitted by statutory regulation or exceeds the permitted use, you will need to obtain permission directly from the copyright holder. To view a copy of this licence, visit http://creativecommons.org/licenses/by/4.0/.

\section{References}

1. Planchard D, Popat S, Kerr K, Novello S et al (2018) Metastatic non-small cell lung cancer: ESMO Clinical Practice Guidelines for diagnosis, treatment and follow-up. Ann Oncol 29(Suppl 4):iv192-iv237. https://doi.org/10.1093/annonc/mdy275

2. Jemal A, Bray F, Center MM, Ferlay J, Ward E, Forman DA (2011) Global cancer statistics. Cancer J Clin 61(2):69-90. https ://doi.org/10.3322/caac.20107

3. Quintero Barceinas RS, Garcia-Regalado A, Arechaga-Ocampo E, Villegas-Sepulveda N, Gonzalez-De la Rosa CH (2015) Alltrans retinoic acid induces proliferation, survival, and migration in A549 lung cancer cells by activating the ERK signaling pathway through a transcription-independent mechanism. BioMed Res Int. https://doi.org/10.1155/2015/404368

4. Karamouzis MV, Konstantinopoulos PA, Papavassiliou AG (2007) Roles of CREB-binding protein (CBP)/p300 in respiratory epithelium tumorigenesis. Cell Res 17:324. https://doi.org/10.1038/ cr.2007.10

5. Karamouzis MV, Ardavanis A, Alexopoulos A et al (2005) Multiple cutaneous acral metastases in a woman with breast adenocarcinoma treated with pegylated liposomal doxorubicin: incidental or aetiological association? Eur J Cancer Care 14(3):267-271. https ://doi.org/10.1111/j.1365-2354.2005.00573.x

6. Arrieta O, Gonzalez-De la Rosa CH, Arechaga-Ocampo E et al (2010) Randomized phase II trial of All-trans-retinoic acid with chemotherapy based on paclitaxel and cisplatin as first-line treatment in patients with advanced non-small-cell lung cancer. J Clin Oncol 28(21):3463-3471. https://doi.org/10.1200/ JCO.2009.26.6452

7. Greve G, Schiffmann I, Lubbert M (2015) Epigenetic priming of non-small cell lung cancer cell lines to the antiproliferative and differentiating effects of all-trans retinoic acid. J Cancer Res Clin Oncol 141(12):2171-2180. https://doi.org/10.1007/s0043 2-015-1987-1

8. Napoli JL (2017) Cellular retinoid binding-proteins, CRBP, CRABP, FABP5: effects on retinoid metabolism, function and related diseases. Pharmacol Ther 173:19-33. https://doi. org/10.1016/j.pharmthera.2017.01.004

9. Noy N (2000) Retinoid-binding proteins: mediators of retinoid action. Biochem J 348 (Pt 3):481-495.

10. Zhuang Y, Faria TN, Chambon P, Gudas LJ (2003) Identification and characterization of retinoic acid receptor beta2 target genes in F9 teratocarcinoma cells. Mol Cancer Res 1(8):619-630. PMID: 12805409

11. Napoli JL (1993) Biosynthesis and metabolism of retinoic acid: roles of CRBP and CRABP in retinoic acid: roles of CRBP and CRABP in retinoic acid homeostasis. J Nutr 23(2 Suppl):362-366. https://doi.org/10.1093/jn/123.suppl_2.362

12. Dirami G, Massaro GD, Clerch LB, Ryan US, Reczek PR, Massaro D (2004) Lung retinol storing cells synthesize and secrete retinoic acid, an inducer of alveolus formation. Am J Physiol Lung Cell Mol Physiol 286:L249. https://doi.org/10.1152/ajplu ng.00140.2003

13. Kuppumbatti YS, Bleiweiss IJ, Mandeli JP, Waxman S, Mira YLR (2000) Cellular retinol-binding protein expression and breast cancer. J Natl Cancer Inst 92:475. https://doi.org/10.1093/ jnci/92.6.475

14. Orlandi A, Ferlosio A, Ciucci A et al (2006) Cellular retinol binding protein-1 expression in endometrial hyperplasia and carcinoma: diagnostic and possible therapeutic implications. Mod Pathol 19:797. https://doi.org/10.1038/modpathol.3800586

15. Doldo E, Costanza G, Ferlosio A et al (2014) CRBP-1 expression in ovarian cancer: a potential therapeutic target. Anticancer Res 34(7):3303-3312

16. Bogos K, Renyi-Vamos F, Kovacs G, Tovari J, Dome B (2008) Role of retinoic receptors in lung carcinogenesis. J Exp Clin Cancer Res 27(1):18. https://doi.org/10.1186/1756-9966-27-18

17. Bushue N, Wan YJ (2010) Retinoid pathway and cancer therapeutics. Adv Drug Deliv Rev 62(13):1285-1298. https://doi. org/10.1016/j.addr.2010.07.003

18. Uray IP, Dmitrovsky E, Brown PH (2016) Retinoids and rexinoids in cancer prevention: from laboratory to clinic. Semin Oncol 43(1):49-64. https://doi.org/10.1053/j.seminoncol.2015.09.002

19. Cavasotto CN, Liu G, James SY, Hobbs PD et al (2004) Determinants of retinoid $\mathrm{X}$ receptor transcriptional antagonism. J Med Chem 47(18):4360-4372. https://doi.org/10.1021/jm030651g

20. Toma S, Emionite L, Fabia G, Spadini N, Vergani L (2003) Chemoprevention of tumors: the role of RAR-beta. Int J Biol Markers 18(1):78-81. https://doi.org/10.5301/jbm.2008.4881

21. Brabender J, Park J, Metzger R, Schneider PM, Lord RV, Holscher AH, Danenberg KD, Danenberg PV (2002) Prognostic significance of cyclooxygenase 2 mRNA expression in nonsmall cell lung cancer. Ann Surg 235(3):440-443. https://doi. org/10.1097/00000658-200203000-00017

22. Mekic-Abazovic A, Music M, Fajkic A, Zerem E (2010) Analysis of chemiotherapeutic protocols efficiency in therapy of advanced non small cell lung cancer. Med Arch 64(2):98-100 
23. Berry DC, O’Byrne SM, Vreeland AC, Blaner WS, Noy N (2012) Cross talk between signaling and vitamin A transport by the retinol-binding protein receptor STRA6. Mol Cell Biol 32(15):31643175. https://doi.org/10.1128/MCB.00505-12

24. Doldo E, Costanza G, Ferlosio A et al (2015) High expression of cellular retinol binding protein-1 in lung adenocarcinoma is associated with poor prognosis. Genes Cancer 6(11-12):490-502. https://doi.org/10.18632/genesandcancer.89

25. Campagnolo L, Costanza G, Francesconi A, Arcuri G, Moscatelli I, Orlandi A (2014) Sortilin expression is essential for pro-nerve growth factor-induced apoptosis of rat vascular smooth muscle cells. PLoS ONE 9:e84969. https://doi.org/10.1371/journ al.pone.0084969

26. Cervelli V, Scioli MG, Gentile P, Doldo E, Bonanno E, Spagnoli LG, Orlandi A (2012) Platelet-rich plasma greatly potentiates insulin-induced adipogenic differentiation of human adiposederived stem cells through a serine/threonine kinase Akt-dependent mechanism and promotes clinical fat graft maintenance. Stem Cells Transl Med 1(3):206-220. https://doi.org/10.5966/ sctm.2011-0052

27. Orlandi A, Pucci S, Ciucci A, Pichiorri F, Ferlosio A, Spagnoli LG (2005) Modulation of clusterin isoforms is associated with all-trans retinoic acid-induced proliferative arrest and apoptosis of intimal smooth muscle cells. Arterioscler Thromb Vasc Biol 25(2):348-353. https://doi.org/10.1161/01.ATV.0000152609 28569.e1

28. Yun CH, Mengwasser KE, Toms AV, Woo MS, Greulich H, Wong KK, Meyerson M, Eck MJ (2008) The T790M mutation in EGFR kinase causes drug resistance by increasing the affinity for ATP. Proc Natl Acad Sci USA 105(6):2070-2075. https://doi. org/10.1073/pnas.0709662105

29. Orlandi A, Ehrlich HP, Ropraz P, Spagnoli LG, Gabbiani G (1994) Rat aortic smooth muscle cells isolated from different layers and at different times after endothelial denudation show distinct biological features in vitro. Arterioscler Thromb 14:982. https://doi. org/10.1161/01.atv.14.6.982

30. Bryan M, Pulte ED, Toomey KC, Pliner L, Pavlick AC, Saunders T, Wieder R (2011) A pilot phase II trial of all-trans retinoic acid (Vesanoid) and paclitaxel (Taxol) in patients with recurrent or metastatic breast cancer. Invest New Drugs 29(6):1482-1487. https://doi.org/10.1007/s10637-010-9478-3

31. Shi Y, Fu X, Hua Y, Han Y, Lu Y, Wang J (2012) The side population in human lung cancer cell line NCI-H460 is enriched in stemlike cancer cells. PLoS ONE 7(3):e33358. https://doi.org/10.1371/ journal.pone. 0033358

32. Jones PA, Baylin SB (2002) The fundamental role of epigenetic events in cancer. Nat Rev Genet 3(6):415-428. https://doi. org/10.1038/nrg816

33. Shtivelman E, Hensing T, Simon GR, Dennis PA, Otterson GA, Bueno R, Salgia R (2014) Molecular pathways and therapeutic targets in lung cancer. Oncotarget 5(6):1392-1433. https://doi. org/10.18632/oncotarget.1891

34. Kim TK, Herbst RS, Chen L (2018) Defining and understanding adaptive resistance in cancer immunotherapy. Trends Immunol 39(8):624-631. https://doi.org/10.1016/j.it.2018.05.001

35. Brabender J, Metzger R, Salonga D, Danenberg KD, Danenberg PV, Holscher AH, Schneider PM (2005) Comprehensive expression analysis of retinoic acid receptors and retinoid $\mathrm{X}$ receptors in non-small cell lung cancer: implications for tumor development and prognosis. Carcinogenesis 26(3):525-530. https://doi. org/10.1093/carcin/bgi006
36. Altucci L, Gronemeyer H (2001) The promise of retinoids to fight against cancer. Nat Rev Cancer 1(3):181-193. https://doi. org $/ 10.1038 / 35106036$

37. Dragnev KH, Petty WJ, Shah SJ, Lewis LD, Black CC, Memoli V, Nugent WC, Hermann T, Negro-Vilar A, Rigas JR, Dmitrovsky E (2007) A proof-of-principle clinical trial of bexarotene in patients with non-small cell lung cancer. Clin Cancer Res 13(6):17941800. https://doi.org/10.1158/1078-0432.CCR-06-1836

38. Ramlau R, Zatloukal P, Jassem J, Schwarzenberger P, Orlov SV, Gottfried M, Pereira JR, Temperley G, Negro-Vilar R, Rahal S, Zhang JK, Negro-Vilar A, Dziewanowska ZE (2008) Randomized phase III trial comparing bexarotene (L1069-49)/cisplatin/vinorelbine with cisplatin/vinorelbine in chemotherapy-naive patients with advanced or metastatic non-small-cell lung cancer: SPIRIT I. J Clin Oncol 26(11):1886-1892. https://doi.org/10.1200/ JCO.2007.12.2614

39. Xu XC (2007) Tumor-suppressive activity of retinoic acid receptor-beta in cancer. Cancer letters 253(1):14-24. https://doi. org/10.1016/j.canlet.2006.11.019

40. Blomhoff $\mathrm{R}$ (1994) Transport and metabolism of vitamin A. Nutr Rev 52(2 Pt 2):S13-S23. https://doi. org/10.1111/j.1753-4887.1994.tb01382.x

41. Underwood BA (1984) Vitamin A and cancer prevention conference-an introduction. J Natl Cancer Inst 73(6):1371-1372

42. Costanza G, Doldo E, Ferlosio A, Tarquini C, Passeri D, Cascella R, Bavetta M, Di Stefani A, Bonifati C, Agostinelli S, Centofanti F, Giardina E, Campione E, Bianchi L, Donati P, Morrone A, Orlandi A (2018) Expression and potential role of cellular retinol binding protein I in psoriasis. Oncotarget 9(95):36736-36749. https://doi.org/10.18632/oncotarget.26314

43. Niles RM (2004) Signaling pathways in retinoid chemoprevention and treatment of cancer. Mutat Res 555(1-2):81-96. https://doi. org/10.1016/j.mrfmmm.2004.05.020

44. Campos B, Centner FS, Bermejo JL, Ali R, Dorsch K, Wan F, Felsberg J, Ahmadi R, Grabe N, Reifenberger G, Unterberg A, Burhenne J, Herold-Mende C (2011) Aberrant expression of retinoic acid signaling molecules influences patient survival in astrocytic gliomas. Am J Pathol 178(5):1953-1964. https://doi. org/10.1016/j.ajpath.2011.01.051

45. Farias E, Ong D, Ghyselinck N, Nakajo S, Kuppumbatti Y, Mira y Lopez R (2005) Cellular retinol-binding protein I, a regulator of breast epithelial retinoic acid receptor activity, cell differentiation, and tumorigenicity. J Natl Cancer Inst 97(1):21-29. https://doi. org/10.1093/jnci/dji004

46. Farias E, Marzan C, Mira-y-Lopez R (2005) Cellular retinol-binding protein-I inhibits PI3K/Akt signaling through a retinoic acid receptor-dependent mechanism that regulates p85-p110 heterodimerization. Oncogene 24(9):1598-1606. https://doi.org/10.1038/ sj.onc. 1208347

47. Kuznetsova ES, Zinovieva OL, Oparina NYu, Prokofjeva MM, Spirin PV, Favorskaya IA, Zborovskaya IB, Lisitsyn NA, Prassolov VS, Mashkova TD (2015) Abnormal expression of genes that regulate retinoid metabolism and signaling in non-small-cell. Lung Cancer 50(2):255-265. https://doi.org/10.1134/S002689331 6020138

Publisher's Note Springer Nature remains neutral with regard to jurisdictional claims in published maps and institutional affiliations. 